\title{
LINGUAGENS, FRONTEIRAS E INTERCULTURALIDADES
}

Maria de Jesus Morais ${ }^{1}$

Elder Andrade de Paula ${ }^{2}$

Os artigos publicados deste Dossiê, em sua maioria, resultaram de um profícuo debate realizado no decorrer da disciplina Linguagem, Fronteira e Interculturalidade, ministrada por nós no primeiro semestre de 2019 no âmbito do PPGLI-UFAC. Após a leitura e avaliação dos trabalhos apresentados pelos discentes ao final do curso, consideramos a pertinência de socializá-los através desta publicação. Selecionamos àqueles que refletiram com maior densidade os debates e objetivos propostos na disciplina.

$\mathrm{Na}$ problematização das relações entre linguagens, fronteiras e interculturalidade privilegiamos os estudos realizados na região fronteiriça formada por Brasil, Peru e Bolívia. Fronteiras estas marcadas, por um lado, por inúmeros conflitos sociais, territoriais e também de emergência de movimentos sociais diversos (indígenas, camponeses, quilombolas entre outros) cujas lutas de resistência se projetaram para além do continente americano. Por outro lado, pela atuação nas três últimas décadas de uma complexa rede de organizações da "sociedade civil", instituições governamentais e agências internacionais de apoio aos movimentos sociais em defesa de seu modo de vida.

As reflexões teóricas sobre a assimilação da interculturalidade na agenda política, suas diferentes interpretações, formas de apropriação, tensões e conflitos pautaram-se nos aportes do debate latino-americano. Como mostra Javier Protzel (2015), muito antes da elaboração do conceito nos Estados Unidos da América na década de 1950, na América Latina a questão intercultural já ocupava um lugar destacado nas preocupações de antropólogos e historiadores, especialmente nos países com maiorias de origem indígena e ou afrodescendentes.

Essa marcação das singularidades do debate latino-americano foi imprescindível para situar as interpretações da dinâmica intercultural nas fronteiras amazônicas e as formas de institucionalização em termos de políticas educacionais. A partir dela, tornou-se mais inteligível as diferenças no posicionamento dos movimentos sociais, notadamente os indígenas, em relação a interculturalidade enquanto fundamento filosófico. Enquanto na Bolívia e Peru emerge como aspiração e compromisso com um projeto político de descolonização do mundo e reorganização da vida a partir da pluralidade cultural, sem hierarquias, no Brasil aparece

1 Instituição: Universidade Federal do Acre, Orcid: https://orcid.org/0000-0002-8053-3549, E-mail: mjmorais@hotmail.com 2 Instituição: Universidade Federal do Acre, Orcid: https://orcid.org/0000-0002-2881-3033, E-mail: elderpaula@uol.com.br 
subordinada a uma forma de institucionalização que reitera as assimetrias socioculturais e por conseguinte a continuidade da colonização do mundo.

A institucionalização do debate da interculturalidade na América Latina, como aponta Chirif (2012), se deu a partir da elaboração de programas de educação bilingue e intercultural. Esta, surge como uma proposta política do movimento indígena frente a implantação do modelo de Estado-nação que desde sempre inviabilizou e, em várias situações exterminou línguas e culturas dos povos originários. Neste contexto, a história da educação, nos revela que a escola oficial, tem empreendido a negação dos discursos das sociedades indígenas e, os considera pré-científicos e sem valor para o processo de modernização e construção dos ditos estados nacionais (RAMIREZ, 2012). Mas a educação intercultural e bilingue tem tido êxitos em países como o Peru, Equador, Guatemala e, algumas poucas experiências no Brasil.

O dossiê Linguagens, Fronteiras e Interculturalidade, contém textos que abordam a construção de currículos interculturais, experiências de atividades em escola indígena, reflexões sobre discursos identitários e luta pela terra e pela vida, além de um artigo que trata da discussão sobre 'instrumentos musicais tradicionais africanos' e nos brinda com a discussão de outras epistemologias de culturas africanas.

Expressando os trânsitos acadêmicos e a ampla circulação do periódico Muiraquitã - Revista de Letras e Humanidades, este volume traz ainda uma dezena e meia de outras contribuições na forma de resenhas e artigos livres, com resultados de pesquisas, experiências profissionais e acadêmicas procedentes de diversas localidades e instituições brasileiras.

\section{REFERÊNCIAS}

CHIRIF, Alberto. Identidad, interculturalidad e inclusión en la Amazonía peruana hoy. En E. Toche (Comp.) Perú Hoy: La gran continuidad. Lima: Centro de Estudios y Promoción del Desarrollo, 2012.

PROTZEL, Javier. Comunicación intercultural: confrontando concepciones y problemas. Venezuela, Correspondencias \& Análisis, $N^{\circ}$ 5, año 2015.

RAMÍREZ, Fernando Prada. Sistemas civilizatorios, bio-territoriais y epistemologías concéntricas. In. LLORENTE, Juan Carlos; SACONA, Unai. Investigación aplicada a la educación intercultural bilingue. Helsinki, Instituto de Ciencias del Comportamiento, 2012. 